\title{
Religious Attendance in a Secular Country Protects Adolescents from Health-Risk Behavior Only in Combination with Participation in Church Activities
}

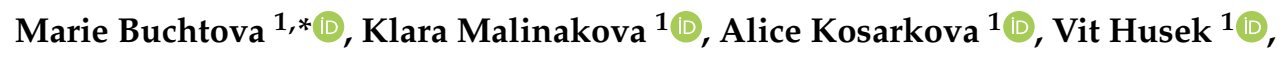 \\ Jitse P. van Dijk ${ }^{1,2,3}$ - and Peter Tavel ${ }^{1}$ \\ 1 Olomouc University Social Health Institute, Palacký University Olomouc, 77111 Olomouc, Czech Republic; \\ klara.malinakova@oushi.upol.cz (K.M.); alice.kosarkova@oushi.upol.cz (A.K.); vit.husek@upol.cz (V.H.); \\ j.p.van.dijk@umcg.nl (J.P.v.D.); peter.tavel@oushi.upol.cz (P.T.) \\ 2 Department of Community and Occupational Medicine, University Medical Center Groningen, \\ University of Groningen, 9713 AV Groningen, The Netherlands \\ 3 Graduate School Kosice Institute for Society and Health, P.J. Safarik University in Kosice, \\ 04011 Kosice, Slovakia \\ * Correspondence: marie.buchtova@oushi.upol.cz; Tel.: +420-721-616-859
}

Received: 18 November 2020; Accepted: 12 December 2020; Published: 15 December 2020

\begin{abstract}
Religiosity and spirituality have been considered to be protective factors of adolescent health-risk behavior (HRB). The aim of this study was to assess the relationship between adolescents' HRB and their religiosity, taking into account their parents' faith and their own participation in church activities. A nationally representative sample ( $n=13377,13.5 \pm 1.7$ years, $49.1 \%$ boys) of Czech adolescents participated in the 2018 Health Behavior in School-aged Children cross-sectional study. We measured religious attendance (RA), faith importance (FI) (both of respondents and their parents), participation in church activities and adolescent HRB (tobacco, alcohol, and cannabis use and early sexual intercourse). We found that neither RA nor FI of participants or their parents had a significant effect on adolescents' HRB. Compared to attending respondents who participate in church activities (AP), non-attending respondents who participate in church activities were more likely to report smoking and early sexual intercourse, with odds ratios (ORs) ranging from 3.14 (1.54-6.39) to 3.82 (1.99-7.35). Compared to AP, non-attending respondents who did not participate in church activities were more likely to report early sexual intercourse, with OR $=1.90$ (1.14-3.17). Thus, our findings show that RA does not protect adolescents from HRB; they suggest that RA protects adolescents from HRB only in combination with participation in church activities.
\end{abstract}

Keywords: adolescents; religiosity; spirituality; health-risk behavior; HBSC study

\section{Introduction}

Adolescent health-risk behavior (HRB) is the subject of many research studies worldwide. Research shows that it may be a predictor of adult risk behavior [1-5]. Although the numbers in the Czech Republic are decreasing, according to data from the Czech 2018 Health Behavior in School-aged Children (HBSC) study, adolescents still have a high prevalence of tobacco and marijuana use: $41 \%$ of fifteen-years old girls and $37 \%$ of fifteen-years old boys have smoked tobacco at least once in their lives, and $21 \%$ of girls and $16 \%$ of boys in this age group have smoked during the last 30 days. Furthermore, $20 \%$ of boys and $17 \%$ of girls have already tried cannabis. In regular marijuana consumption, Czech adolescents hold 17th place out of 42 surveyed countries with $8 \%$ of boys and $7 \%$ of girls who have regular contact with marijuana. Moreover, $76 \%$ of girls and about the same number of boys have drunk alcohol [6]. Because of these high numbers based on the data from 45 countries 
that participated in the $2017 / 2018$ HBSC survey, it is necessary to search for ways to protect young people from these risks.

Religiosity and spirituality (R/S) are often considered as protective factors of risk behavior [7]. They may help to postpone the onset of smoking or reduce its occurrence among adolescents [8,9]. Moreover, R/S can also act as a protective factor of sexual behavior $[10,11]$, and religious attendance (RA) is associated with a lower alcohol and substance use [12-15]. However, some research confirmed gender differences in the relationship between R/S and HRB [9,15], and some studies [16] have not found a link between spirituality and substance use among adolescents. An explanation might be that adolescent risk behavior is influenced by a lot of factors. In terms of adolescents' smoking, the influence of their parents and peers is significant, and adolescents tend to start smoking when their parents and peers smoke [17,18]. An adolescents' decision to start smoking is also related to their personal faith practice and belonging to a religious community [8]. Furthermore, Kim-Spoon et al. found an inverse correlation between adolescent substance use and their parents' religiosity [19]. It is possible that religiosity is associated with a greater parental control [20] and higher self-control in adolescents, thus reducing the tendency to substance abuse [19]. In the same way, the influence of a religious peer group could be a possible protective factor in adolescent risk behavior. Some sources, e.g., Bartkowski et al. [21], also take into account the influence of a faith community on human development, suggesting that positive human development may be more strongly influenced by a religious community than by family.

According to earlier studies, the Czech Republic was considered one of the most secular or even atheistic countries in the world [22,23], with a high percentage of religiously unaffiliated people $[24,25]$. The church attendance rate is quite low in the Czech republic, only $8 \%$ citizens go to church regularly at least once a month [26]. Compared to other European nations, the position of religion in the Czech Republic has significantly weakened [22] and Czechs are characterized by the weakest relationship to the Christian church as an institution. However, Christianity itself is not perceived so negatively [23], and so contemporary Czech society can be described as post-Christian rather than secular or atheistic. It appears that family education is still a key factor in the continuity of religious life in secular Czech society [27]. Research has thus far not focused much on the transmission of faith and the influence of a religious community on adolescents' behavior. Therefore, the aim of this article is to analyze the relationship of health-risk behavior and adolescents' religious attendance and faith in a secular environment, taking the faith of their parents and a background among believing/religious peers into account.

\section{Materials and Methods}

\subsection{Participants and Procedure}

A nationally representative sample of Czech boys and girls was obtained through the 2018 Health Behavior in School-aged Children (HBSC) study. This cross-sectional WHO collaborative study focused on health and health-related behavior and their socioeconomic determinants in 11-, 13-, and 15-year-old children. The HBSC study has been conducted at 4-year intervals since 1983/84 and now includes 48 countries across Europe and North America. According to the HBSC study protocol, schools were selected randomly after stratification by region, school size, and type of school (primary schools vs. secondary schools). Out of 227 contacted schools, 7 refused to participate and were substituted by schools of similar size in their close neighborhood; thus, the school response rate was $97 \%$. Then, classes from the 5 th, 7 th, and 9 th grades, in general corresponding to age the categories of 11-, 13-, and 15-year-olds, were selected at random, one from each grade per school. Data from 13,885 pupils were obtained (response rate $86.4 \%$ ). The majority of non-response was due to illness $(8.87 \%)$ or other reasons for absence $(4.18 \%)$; however, 84 children refused to participate in the survey $(0.5 \%)$. Of the sample, 238 questionnaires were excluded due to the problems found during the check of internal consistency and due to missing responses to key questions, and another 270 respondents were 
excluded because their age lay outside the age-range of the specific class. Thus, 13,377 questionnaires were considered valid.

Data was collected between May and June 2018 and was gathered through online surveys. Instructions were given by trained administrators with no teachers present in the classroom in order to reduce response bias. Each participant received a unique application code from the administrator to access to the questionnaire. Respondents had one school lesson $(45 \mathrm{~min}$ ) to complete the questionnaire. Participation in the survey was anonymous and voluntary. All survey procedures for each data collection cycle have been saved and can be downloaded [28]. The Czech HBSC study was conducted under the auspices of the Ministry of Education, Youth and Sports of the Czech Republic and the World Health Organization Country Office in the Czech Republic. The study design was approved by the Ethics Committee of the Faculty of Physical Culture, Palacký University Olomouc (No. 9/2016).

\subsection{Measures}

"Religious attendance" was measured by the question: "How often do you go to church or to religious sessions?" with possible answers: several times a week/once a week/once a month/several times a year/rarely/not at all. Weekly attendance is compulsory for most Czech religions [29], so participants who reported at least one weekly religious meeting were dichotomized as attending, as used in previous studies based on HBSC data [15]. Parental religious attendance was measured in the same way by asking questions similar to those asked of adolescents: "How often does your father/mother go to church or to religious sessions?" and was dichotomized in the same way as adolescents' religious attendance.

"Importance of faith" was measured by the question: "How important is faith in God for you?" Possible answers were on a scale from 1 (not at all) through 4 (neither important nor unimportant) to 7 (absolutely). According to the previously used dichotomization [15], participants responding from 5 to 7 on the scale were dichotomized as those for whom faith is important. The importance of faith for parents was examined in the same way by the question: "In your view, how important is faith in God for your father/mother?" and was dichotomized in the same way.

"Participation in church activities" was assessed by the question: "In your free time, do you take part in any religious activities (e.g., church meetings, singing in church choirs)?" The possible answers were "Yes" or "No".

"Smoking" was assessed by the question: "How often do you currently smoke tobacco?" with possible answers: every day/at least once a week but not daily/less often than once a week/I don't smoke. According to the HBSC dichotomization [30,31], respondents who smoked at least once a week were classified as smokers, the rest as non-smokers. Moreover, this dichotomization has been used for Czech adolescents before [32].

"Drinking" was measured by the question: "How many days (if ever) have you drunk alcohol in the last 30 days?" with possible answers: never/1-2 days/3-5 days/6-9 days/10-19 days/20-29 days/30 days or more. Respondents were classified as alcohol consumers if they reported drinking at least three days in the last month, as used in previous studies based on HBSC data [32-34].

"Recent cannabis use" was assessed by the question: "Have you used cannabis (weed, ganja) in the last 30 days?" with the answers: never/1-2 days/3-5 days/6-9 days/10-19 days/20-29 days/30 days or more. As in some previous studies [35,36], those who answered "never" or "1-2 days" were classified as cannabis non-users, the rest of the respondents as users.

"Early sexual intercourse" was measured by the question: "Have you ever had sexual intercourse (sometimes this is called "making love", "having sex", etc.)?" Possible answers were "Yes" or "No".

"Age, gender, socioeconomic status and social media" use were considered potentially confounding variables and were obtained by the questionnaire. The socioeconomic status of the respondents' families was assessed using the Family Affluence Scale (FAS). This scale examines the number of cars in the family, having one's own bedroom, the number of computers (including laptops and tablets) in the household, the number of bathrooms, dishwasher ownership, and the number of family holidays 
abroad last year. The summary score ranges from 10 to 13 and, according to HBSC recommendations, we transformed ordinal data into an interval scale with a normalized range (from 0 to 1 , with a higher score indicating higher socioeconomic position) and distribution.

Social media use of the respondents was assessed using the 9-item Social Media Disorder Scale [37] measuring social media addiction degree. The wording of the questions was: "We are interested in your experiences with social media. The term social media refers to social network sites (e.g., Facebook, Instagram, Twitter) and instant messengers (e.g., WhatsApp, Snapchat, Facebook messenger). During the past year, have you ... "followed by nine disorder characteristics (e.g., regularly found that you can't think of anything else but the moment that you will be able to use social media again?). Possible answers to each item were "Yes" or "No". We performed a summary score of all "Yes" answers.

\subsection{Statistical Analyses}

As a first step, we described the background characteristics of the sample. The normality of the data was verified using the Shapiro-Wilk test. Since the data was not normally distributed, non-parametric methods were used for the statistical analyses. Then, we assessed the associations of various health-risk behaviors with religious attendance (Model 1) and the importance of faith (Model 2) for both the respondents themselves and their parents using binary logistic regression models. Each model was first tested as a crude one and was consequently adjusted for gender, age, socioeconomic status, and social media use. In the same way we used a binary logistic model to assess the associations between health-risk behaviors and different combinations of religious attendance and church activities. All analyses were performed using the statistical software package IBM SPSS version 25 (New York, NY, USA).

\section{Results}

\subsection{Description of the Population}

The background characteristics of the sample are presented in Table 1, which also describes the prevalence of the four types of health-risk behavior for the whole sample as well as for the sample divided according to RA and according to importance of faith. Of the whole sample, 5.9\% respondents attended church services at least weekly and $17.8 \%$ reported that faith is personally important for them. Regarding RA and importance of faith in parents, $6 \%$ of respondents reported that their mothers attended church at least once a week (5.2\% for fathers), and 20\% (respectively $17.2 \%$ ) of adolescents reported faith is important for their mothers (respectively fathers). The adolescents' own RA was highly correlated with their mothers' RA (Spearman's $r=0.84(p<0.01))$ and their fathers' RA $(r=0.79$, $p<0.01)$. Importance of faith for the respondents was also highly correlated with their parents' importance of faith (with $r=0.85$ for mothers and $r=0.82$ for fathers, respectively). 
Table 1. Sample characteristics by religious attendance and importance of faith.

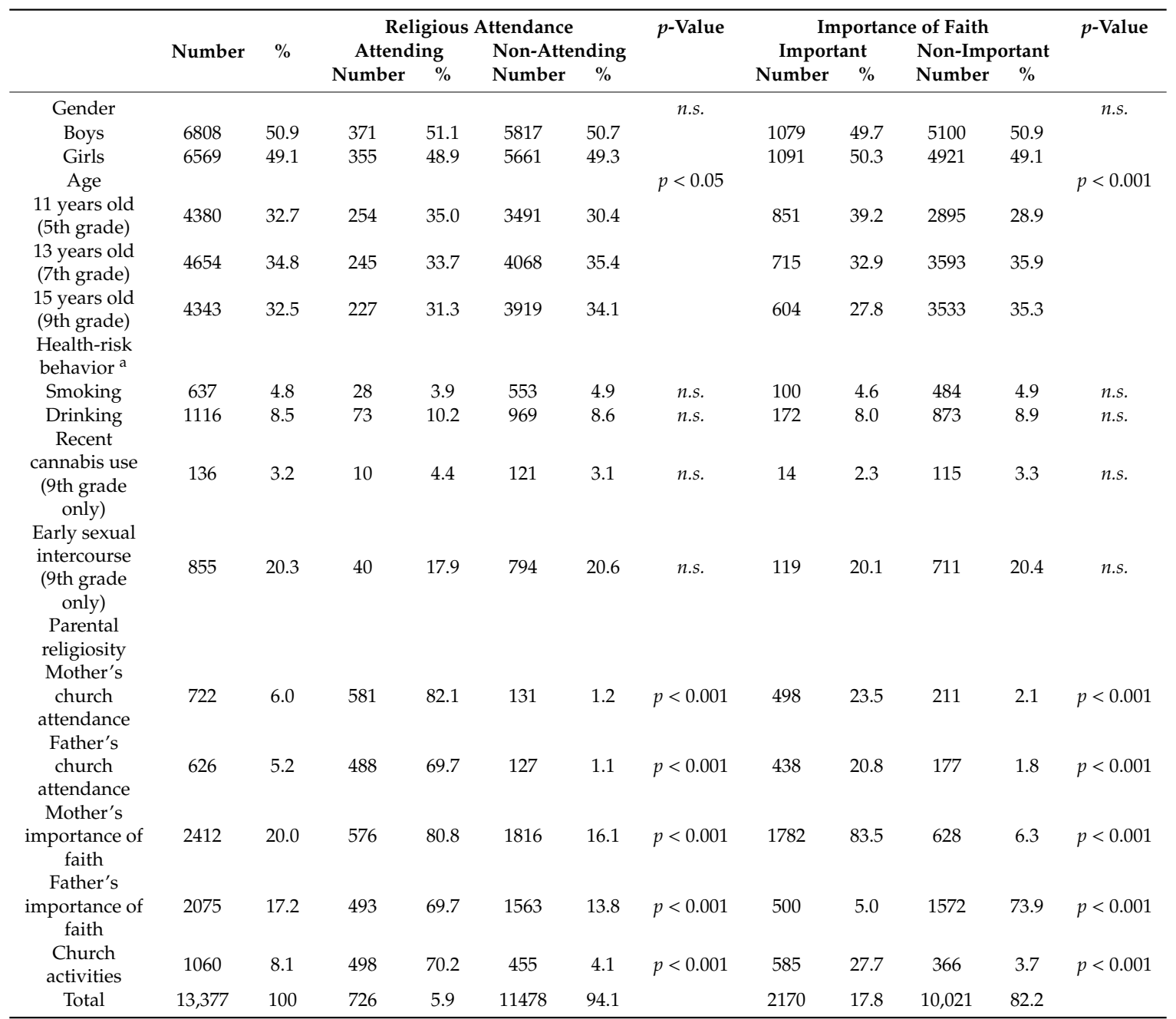

Notes: Number of missing cases per variable: Smoking-104; Drinking—4943; Recent cannabis use—9089; Early sexual intercourse-9167; Religious attendance-1173; Importance of faith-1186; Mother's church attendance-1257; Father's church attendance-1306; Mother's importance of faith-1299; Father's importance of faith-1316; Church activities-301. ${ }^{\text {a }}$ Only numbers regarding the respondents with the occurrence of health-risk behavior are presented.

\subsection{Health-Risk Behavior}

Table 2 shows the associations of religious attendance and importance of faith with various health-risk behaviors, adjusted for age, gender, socioeconomic status, and social media use. We found almost no significant association of health-risk behavior and church attendance (Model 1) or the importance of faith (Model 2), either in terms of respondents or of their parents. However, we found a significant association between early sexual intercourse and respondents' fathers church attendance. Specifically, respondents whose fathers did not attend church were 1.6 times more likely to report early sexual intercourse. 
Table 2. Associations of adolescent smoking, drinking, recent cannabis use, and early sexual intercourse with religious attendance, importance of faith, crude and, adjusted for age, gender, socioeconomic status (FAS), and social media use (odds ratios and 95\% confidence intervals).

\begin{tabular}{|c|c|c|c|c|c|c|c|c|c|}
\hline & & \multicolumn{2}{|c|}{ Smoking } & \multicolumn{2}{|c|}{ Drinking } & \multicolumn{2}{|c|}{$\begin{array}{c}\text { Recent Cannabis Use } \\
\text { (15 Years Old) }\end{array}$} & \multicolumn{2}{|c|}{$\begin{array}{c}\text { Early Sexual Intercourse } \\
\text { (15 Years Old) }\end{array}$} \\
\hline \multicolumn{2}{|c|}{ Model 1: Religious Attendance } & Crude & Adjusted & Crude & Adjusted & Crude & Adjusted & Crude & Adjusted \\
\hline Respondent & Non-attending vs. attending & $\begin{array}{c}1.26 \\
(0.85-1.85)\end{array}$ & $\begin{array}{c}1.25 \\
(0.82-1.90)\end{array}$ & $\begin{array}{c}0.83 \\
(0.64-1.06)\end{array}$ & $\begin{array}{c}0.78 \\
(0.59-1.03)\end{array}$ & $\begin{array}{c}0.69 \\
(0.36-1.34)\end{array}$ & $\begin{array}{c}0.65 \\
(0.33-1.27)\end{array}$ & $\begin{array}{c}1.18 \\
(0.83-1.68)\end{array}$ & $\begin{array}{c}1.46 \\
(1.00-2.16)\end{array}$ \\
\hline Mother & Non-attending vs. attending & $\begin{array}{c}1.23 \\
(0.84-1.81)\end{array}$ & $\begin{array}{c}1.17 \\
(0.77-1.78)\end{array}$ & $\begin{array}{c}0.83 \\
(0.64-1.06)\end{array}$ & $\begin{array}{c}0.81 \\
(0.61-1.07)\end{array}$ & $\begin{array}{c}0.76 \\
(0.38-1.53)\end{array}$ & $\begin{array}{c}0.72 \\
(0.36-1.45)\end{array}$ & $\begin{array}{c}0.95 \\
(0.68-1.32)\end{array}$ & $\begin{array}{c}1.14 \\
(0.79-1.65)\end{array}$ \\
\hline Father & Non-attending vs. attending & $\begin{array}{c}1.06 \\
(0.72-1.56)\end{array}$ & $\begin{array}{c}1.08 \\
(0.71-1.65)\end{array}$ & $\begin{array}{c}0.98 \\
(0.74-1.31)\end{array}$ & $\begin{array}{c}1.02 \\
(0.74-1.39)\end{array}$ & $\begin{array}{c}0.58 \\
(0.30-1.12)\end{array}$ & $\begin{array}{c}0.55 \\
(0.28-1.07)\end{array}$ & $\begin{array}{c}1.24 \\
(0.85-1.80)\end{array}$ & $\begin{array}{c}1.61 \\
(1.05-2.46)^{*}\end{array}$ \\
\hline \multicolumn{10}{|c|}{ Model 2: Importance of faith } \\
\hline Respondent & Unimportant vs. important & $\begin{array}{c}1.05 \\
(0.84-1.31)\end{array}$ & $\begin{array}{c}0.90 \\
(0.71-1.15)\end{array}$ & $\begin{array}{c}1.11 \\
(0.94-1.32)\end{array}$ & $\begin{array}{c}0.96 \\
(0.80-1.16)\end{array}$ & $\begin{array}{c}1.42 \\
(0.81-2.49)\end{array}$ & $\begin{array}{c}1.87 \\
(0.97-3.62)\end{array}$ & $\begin{array}{c}1.02 \\
(0.82-1.27)\end{array}$ & $\begin{array}{c}1.07 \\
(0.85-1.35)\end{array}$ \\
\hline Mother & Unimportant vs. important & $\begin{array}{c}1.22 \\
(0.98-1.53)\end{array}$ & $\begin{array}{c}1.07 \\
(0.84-1.36)\end{array}$ & $\begin{array}{c}1.04 \\
(0.89-1.22)\end{array}$ & $\begin{array}{c}0.90 \\
(0.76-1.07)\end{array}$ & $\begin{array}{c}1.21 \\
(0.74-1.98)\end{array}$ & $\begin{array}{c}1.22 \\
(0.72-2.05)\end{array}$ & $\begin{array}{c}0.96 \\
(0.79-1.18)\end{array}$ & $\begin{array}{c}0.96 \\
(0.78-1.19)\end{array}$ \\
\hline Father & Unimportant vs. important & $\begin{array}{c}1.00 \\
(0.80-1.26)\end{array}$ & $\begin{array}{c}0.84 \\
(0.66-1.07)\end{array}$ & $\begin{array}{c}1.19 \\
(0.99-1.42)\end{array}$ & $\begin{array}{c}1.02 \\
(0.84-1.24)\end{array}$ & $\begin{array}{c}1.13 \\
(0.66-1.92)\end{array}$ & $\begin{array}{c}1.26 \\
(0.70-2.28)\end{array}$ & $\begin{array}{c}0.94 \\
(0.75-1.16)\end{array}$ & $\begin{array}{c}0.95 \\
(0.75-1.20)\end{array}$ \\
\hline
\end{tabular}




\subsection{Church Activities}

Table 3 presents the associations of identical health-risk behaviors with different combinations of religious attendance and church activities, adjusted for age, gender, socioeconomic status, and social media use. Respondents who reported religious attendance but did not participate in any church activity were more likely to use alcohol, although the result was significant only for the crude model (a 72\% increase in the odds) and not for the adjusted one. However, for a combination of religious non-attendance with participation in church activities, the odds ratios were significantly increased for smoking, drinking, and early sexual intercourse, although the results for cannabis use were significant for the crude model only. Respondents who neither attended religious meetings nor participated in church activities were 1.90 times more likely to report early sexual intercourse. See Figure 1 for graphical representation.

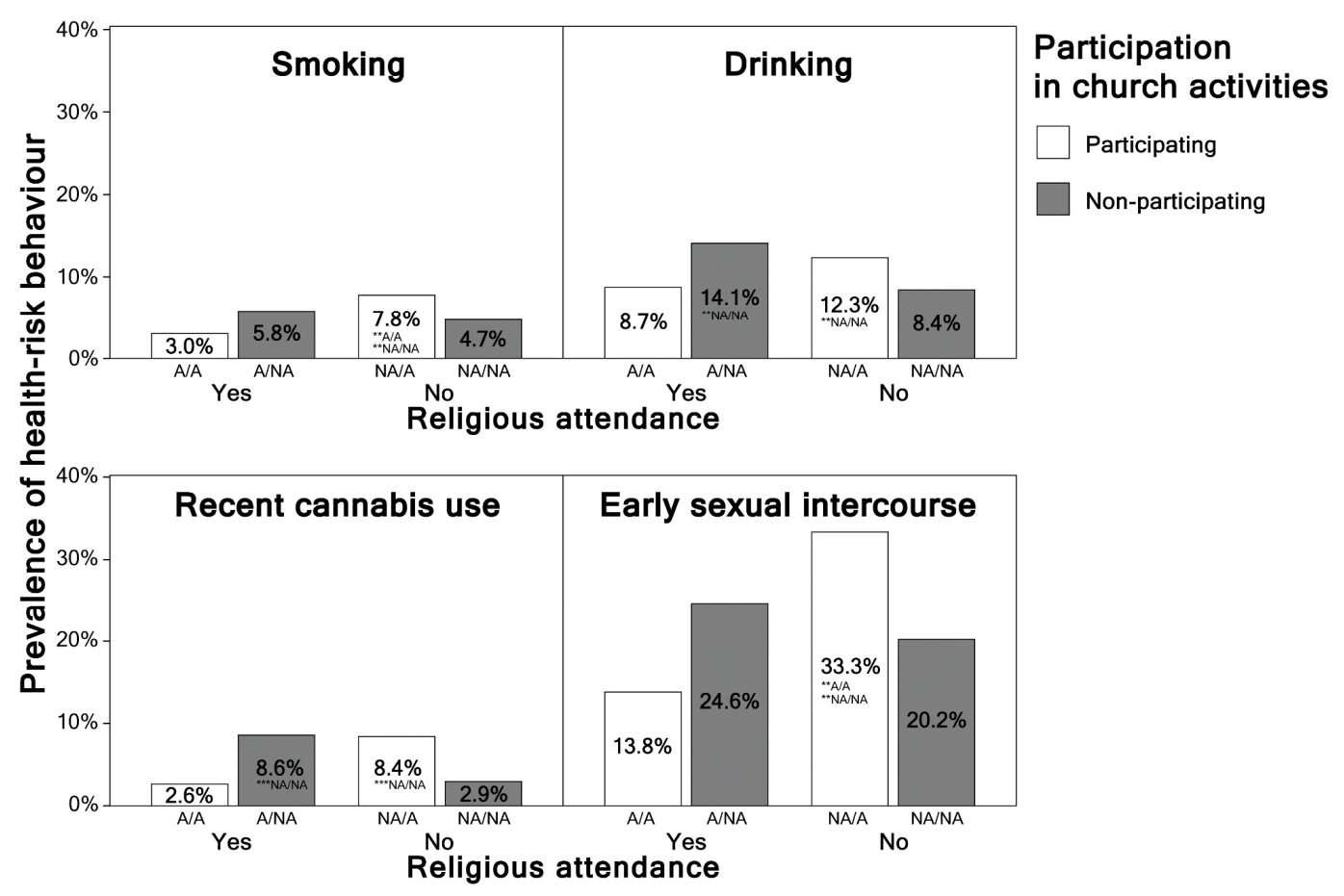

Figure 1. Prevalence of adolescent smoking, drinking, recent cannabis use, and early sexual intercourse in groups with different combinations of religious attendance and participation in church activities (Czech Republic, 2018). (Notes: ${ }^{* *} p<0.01,{ }^{* * *} p<0.001 ; \mathrm{A} / \mathrm{A}=$ attending/church activities; $\mathrm{A} / \mathrm{NA}=$ attending/no church activities; NA/A = non-attending/church activities; NA/NA = non-attending/no church activities). 
Table 3. Associations of adolescent smoking, drinking, recent cannabis use, and early sexual intercourse with different combinations of religious attendance with church activities, crude and, adjusted for age, gender, socioeconomic status (FAS), and social media use (odds ratios and $95 \%$ confidence intervals)

\begin{tabular}{|c|c|c|c|c|c|c|c|c|}
\hline & \multicolumn{2}{|c|}{ Smoking } & \multicolumn{2}{|c|}{ Drinking } & \multicolumn{2}{|c|}{$\begin{array}{l}\text { Recent Cannabis Use } \\
\text { (15 Years Old) }\end{array}$} & \multicolumn{2}{|c|}{$\begin{array}{l}\text { Early Sexual Intercourse } \\
\text { (15 Years Old) }\end{array}$} \\
\hline & Crude & Adjusted & Crude & Adjusted & Crude & Adjusted & Crude & Adjusted \\
\hline Attendance + Church activities & $1^{* *}$ & $1 * *$ & $1 * *$ & $1^{* *}$ & $1 * *$ & 1 & $1 * *$ & $1 * *$ \\
\hline Attendance + No church activities & $\begin{array}{c}1.97 \\
(0.91-4.28)\end{array}$ & $\begin{array}{c}2.26 \\
(0.97-5.26)\end{array}$ & $\begin{array}{c}1.72 \\
(1.04-2.83) *\end{array}$ & $\begin{array}{c}1.32 \\
(0.76-2.29)\end{array}$ & $\begin{array}{c}3.47 \\
(0.95-12.71)\end{array}$ & $\begin{array}{c}3.65 \\
(0.98-13.60)\end{array}$ & $\begin{array}{c}2.04 \\
(1.00-4.17)\end{array}$ & $\begin{array}{c}2.05 \\
(0.93-4.52)\end{array}$ \\
\hline $\begin{array}{l}\text { Non-attendance }+ \\
\text { Church activities }\end{array}$ & $\begin{array}{c}2.71 \\
(1.46-5.02) * *\end{array}$ & $\begin{array}{c}3.14 \\
(1.54-6.39) * *\end{array}$ & $\begin{array}{c}1.47 \\
(0.97-2.24)\end{array}$ & $\begin{array}{c}1.38 \\
(0.87-2.21)\end{array}$ & $\begin{array}{c}3.39 \\
(1.04-11.11) *\end{array}$ & $\begin{array}{c}1.44 \\
(0.35-5.95)\end{array}$ & $\begin{array}{c}3.12 \\
(1.72-5.67)^{* * *}\end{array}$ & $\begin{array}{c}3.82 \\
(1.99-7.35)^{* * *}\end{array}$ \\
\hline $\begin{array}{l}\text { Non-attendance }+ \\
\text { No church activities }\end{array}$ & $\begin{array}{c}1.59 \\
(0.94-2.68)\end{array}$ & $\begin{array}{c}1.74 \\
(0.96-3.14)\end{array}$ & $\begin{array}{c}0.96 \\
(0.70-1.33)\end{array}$ & $\begin{array}{c}0.84 \\
(0.60-1.19)\end{array}$ & $\begin{array}{c}1.12 \\
(0.41-3.08)\end{array}$ & $\begin{array}{c}1.13 \\
(0.41-3.13)\end{array}$ & $\begin{array}{c}1.58 \\
(1.00-2.52)\end{array}$ & $\begin{array}{c}1.90 \\
(1.14-3.17) *\end{array}$ \\
\hline
\end{tabular}

Notes: ${ }^{*} p<0.05,{ }^{* *} p<0.01,{ }^{* * *} p<0.001$ 


\section{Discussion}

The aim of this study was to assess the relationship between adolescent health-risk behavior and their religiosity, also taking into account their parents' faith and participation in church activities. The results show that neither church attendance nor the importance of faith in adolescents' personal life had a significant effect on their health-risk behavior. However, a combination of religious attendance and participation in church activities was associated with generally lower adolescent health-risk behavior. Adolescents who did not attend church but participated in church activities at the same time turned out to be the most vulnerable group in terms of risk behavior. This group was found to have a significantly higher chance for all measured types of health-risk behavior. Respondents who did not attend church or religious communities regularly had a higher chance of early sexual intercourse.

We found that religious attendance or the importance of faith in the personal life of adolescents alone have almost no significant impact on their health-risk behavior. Moreover, the only significant relationship emerging from our results does not relate directly to the religiosity of the participants, but to the religiosity of their fathers. These findings differ from the results of some previous studies, which reported an inverse relationship between adolescent $R / S$ and substance use [12-14,38] or early sexual intercourse [11,39]. Many recent studies have shown that R/S reduces alcohol consumption [40-44] or delays the onset of alcohol abuse in adolescents [45]. However, some studies have come to different conclusions. Pokhrel et al. [16] reported no significant associations between spirituality and substance use. Moreover, according to Hannauer et al. [46], the importance of religion significantly increases young people's perceptions of the risk of alcohol abuse and cannabis use, but has no effect on the perceived risk of smoking. When we focus on the European environment, the results of recent similar research suggest that the relationship between religiosity and risky behavior in adolescents also differs by gender [9,15] and regions $[15,16,47,48]$. In contrast to the results of [47] or [14], our study did not confirm the inverse relationship between the religiosity and alcohol consumption and cannabis use in adolescents, respectively.

The different conclusions may be caused by different methodological approach. As multinomial constructs, both religiosity and spirituality are difficult to define, and they often overlap in the scientific literature [38]. Furthermore, a different methodological approach can lead to a different definition of variables and measurement. To compare, Good and Willoughby [12] discuss institutional (e.g., church attendance and presence at religious gatherings) and personal (e.g., personal experience with the sacred, and the frequency of personal prayer) R/S.

Furthermore, we found that participation in regular church worship is perceived as an external manifestation of $R / S$ and the subjective importance of faith in personal life as personal R/S. Moreover, it should also be noted that a secular environment can play a role, as the Czech Republic is considered one of the most secular countries in the world [25]. In contrast, most studies on adolescent R/S and its impact on health-risk behavior have been conducted in predominantly religious countries $[12,19,49]$. The results of most research, therefore, agree with the well-established view of the inverse relationship between spirituality and risky behavior, which, however, does not correspond to our findings.

We found that religious attendance was a protective factor for health-risk behavior when combined with participation in church activities. Compared to these respondents, the adolescents who only participated in church activities without religious attendance were more likely to report higher health-risk behaviors. Thus, our results are in accordance with the findings of Malinakova et al. [29], who reported that mere church attendance has only a limited impact on adolescent health-risk behavior. Their study also showed the importance of internalization of religious values in order to protect adolescents from risk behavior. In our case, non-attending respondents who participate in church activities can represent adolescents with internal spiritual needs who do not consider regular church attendance as a form of fulfilment. Thus, adolescents' church non-attendance can be seen as a form of rejection of a formal and somehow compulsory duty. Such refusal of standards may be further manifested by increased tendency for risk behavior. In addition, our results, highlighting 
the importance of internalizing religious values are consistent with some recent findings $[50,51]$ that discrepancies in the religious values of parents and adolescents lead to higher levels of HRB.

In our study, religious attendance was protective for adolescent health-risk behavior only when combined with participation in other church activities. Thus, our results confirm the conclusions of many studies [52-54] that the influence of peer groups is crucial in terms of risky behavior of adolescents. They extend the findings of other studies reporting a protective role of $R / S[7,10,12]$ by also stressing the importance of sharing religious values with peers, especially in a secular environment. However, it is obvious that religious activities alone, without regular church attendance, are not sufficient for protecting adolescents from health-risk behavior.

\subsection{Strengths and Limitations}

The main strength of our study is its large and representative sample size, together with a high response rate. Another strength is the use of the established HBSC methodology. However, the relatively small number of respondents who attend church regularly and consider religious faith important can be seen as a limitation, which may have decreased the power of the study, especially when combined with participation in religious activities. A further limitation can be informational bias, as our data are self-referenced and this can be influenced by social desirability. The last limitation is the cross-sectional study design, which does not allow us to draw conclusions on causalities.

\subsection{Implications}

Our study highlights the importance of the influence of peers and informal groups on the health-risk behavior of adolescents. In addition to regular church attendance and the importance of faith for personal life, it is the peer groups that can encourage non-risky behavior. Our findings may be important for people working with children and young people in the field of education, social, or pastoral care. Particularly in pastoral work, various church communities may play an effective role in the prevention of adolescent health-risk. Workers in this area should also be informed that non-attending respondents who participate in church activities might represent a more vulnerable group.

Our results also show that due to the ambiguity of the definitions of religiosity and spirituality there is no universal question to measure them. Especially in a secular country, the influence of the environment needs to be taken into account. Further research is needed for a deeper understanding of the function of peer groups within church communities and of their impact on risk behavior, especially their behavior as a subculture.

\section{Conclusions}

We found that mere religious attendance or the perceived importance of faith have a negligible impact on adolescent health-risk behavior. Religious attendance was found to be protective, but only in combination with participation in church activities. In contrast, the most vulnerable group of respondents were those who did not attend church regularly but participated in church-organized activities. The supportive role of church communities and religious peer groups in terms of prevention of health-risk behavior can be a subject of further research.

Author Contributions: Conceptualization, M.B., K.M., A.K., V.H., J.P.v.D. and P.T.; methodology, M.B., K.M., A.K. and J.P.v.D.; formal analysis, K.M. and A.K.; investigation, M.B., K.M., A.K. and P.T.; resources, P.T.; data curation, P.T.; writing—original draft preparation, M.B. and K.M.; writing—review and editing, K.M., A.K., J.P.v.D., V.H. and P.T.; visualization, M.B. and K.M.; supervision, K.M., J.P.v.D., V.H. and P.T.; project administration, J.P.v.D., P.T. and K.M.; funding acquisition, J.P.v.D., P.T. and K.M. All authors have read and agreed to the published version of the manuscript.

Funding: This study was supported by the Grant Agency of the Czech Republic, project “Biological and psychological aspects of spiritual experience and their associations with health" (contract number 19-19526S), and by the Sts Cyril and Methodius Faculty of Theology of Palacký University in Olomouc, internal project "Psychological, Social and Biological Determinants of Health" (grant number IGA-CMTF-2020-006).

Conflicts of Interest: The authors declare no conflict of interest. 


\section{References}

1. Ciocanel, O.; Power, K.; Eriksen, A.; Gillings, K. Effectiveness of Positive Youth Development Interventions: A Meta-Analysis of Randomized Controlled Trials. J. Youth Adolesc. 2017, 46, 483-504. [CrossRef]

2. Kaplan, D.L.; Jones, E.J.; Olson, E.C.; Yunzal-Butler, C.B. Early Age of First Sex and Health Risk in an Urban Adolescent Population. J. Sch. Health 2013, 83, 350-356. [CrossRef]

3. Patrick, M.E.; O'Malley, P.M.; Johnston, L.D.; Terry-McElrath, Y.M.; Schulenberg, J.E. HIV/AIDS Risk Behaviors and Substance Use by Young Adults in the United States. Prev. Sci. 2012, 13, 532-538. [CrossRef]

4. Patrick, E.M.; Schulenberg, J.E. Prevalence and Predictors of Adolescent Alcohol Use and singe Drinking in the United States. Alcohol Res.-Curr. Rev. 2013, 35, 193-200.

5. Virtanen, P.; Nummi, T.; Lintonen, T.; Westerlund, H.; Hägglöf, B.; Hammarström, A. Mental health in adolescence as determinant of alcohol consumption trajectories in the Northern Swedish Cohort. Int. J. Public Health 2015, 60, 335-342. [CrossRef]

6. Inchley, J.; Currie, D.; Budisavljevic, S.; Torsheim, T.; Jåstad, A.; Cosma, A.; Kelly, C.; Arnarsson, Á.M. (Eds.) Spotlight on Adolescent Health and Well-Being: Findings from the 2017/2018 Health Behavior in School-Aged Children (HBSC) Survey in Europe and Canada; WHO Regional Office for Europe: Copenhagen, Denmark, 2020.

7. Koenig, H.G. Religion, spirituality, and health: The research and clinical implications. ISRN Psychiatry 2012, 2012, 278730-278733. [CrossRef]

8. Nonnemaker, J.; McNeely, C.A.; Blum, R.W. Public and, private domains of religiosity and adolescent smoking transitions. Soc. Sci. Med. 2006, 62, 3084-3095. [CrossRef] [PubMed]

9. Kovacs, E.; Piko, B.F.; Fitzpatrick, K.M. Religiosity as a Protective Factor Against Substance Use Among Hungarian High School Students. Subst. Use Misuse 2011, 46, 1346-1357. [CrossRef] [PubMed]

10. Burdette, M.A.; Hill, T.D. Religious Involvement and Transitions into Adolescent Sexual Activities. Sociol. Relig. 2009, 70, 28-48. [CrossRef]

11. Harakeh, Z.; De Looze, M.E.; Schrijvers, C.T.; Van Dorsselaer, S.A.; Vollebergh, W.A. Individual and environmental predictors of health risk behaviors among Dutch adolescents: The HBSC study. Public Health 2012, 126, 566-573. [CrossRef] [PubMed]

12. Good, M.; Willoughby, T. Institutional and Personal Spirituality/Religiosity and Psychosocial Adjustment in Adolescence: Concurrent and Longitudinal Associations. J. Youth Adolesc. 2014, 43, 757-774. [CrossRef] [PubMed]

13. Piko, B.F.; Kovács, E.; Kriston, P.; Fitzpatrick, K.M. “To believe or not to believe?” Religiosity, spirituality, and alcohol use among Hungarian adolescents. J. Stud. Alcohol Drugs 2012, 73, 666-674. [CrossRef] [PubMed]

14. Haug, S.; Núñez, C.L.; Becker, J.; Gmel, G.; Schaub, M.P. Predictors of onset of cannabis and other drug use in male young adults: Results from a longitudinal study. BMC Public Health 2014, 14, 1202. [CrossRef] [PubMed]

15. Pitel, L.; Madarasova Geckova, A.; Kolarcik, P.; Halama, P.; Reijneveld, S.A.; van Dijk, J.P. Gender differences in the relationship between religiosity and health-related behavior among adolescents. J. Epidemiol. Community Health 2012, 66, 1122-1128. [CrossRef]

16. Pokhrel, P.; Masagutov, R.; Kniazev, V.; Sussman, S. Health-as-a-value, spirituality, and cigarette and alcohol use among Russian high school students. J. Prim. Prev. 2012, 33, 239-248. [CrossRef]

17. Al-Zalabani, A.; Kasim, K. Prevalence and predictors of adolescents' cigarette smoking in Madinah, Saudi Arabia: A school-based cross-sectional study. BMC Public Health 2015, 15, 17. [CrossRef]

18. Madarasova Geckova, A.; Stewart, R.; van Dijk, J.P.; Orosová, O.; Groothoff, J.W.; Post, D. Influence of socio-economic status, parents and peers on smoking behavior of adolescents. Eur. Addict. Res. 2005, 11, 204-209. [CrossRef]

19. Kim-Spoon, J.; Farley, J.P.; Holmes, C.; Longo, G.S.; McCullough, M.E. Processes linking parents' and adolescents' religiousness and adolescent substance use: Monitoring and self-control. J. Youth Adolesc. 2014, 43, 745-756. [CrossRef]

20. Malinakova, K.; Trnka, R.; Bartuskova, L.; Glogar, P.; Kascakova, N.; Kalman, M.; Van Dijk, J.P.; Tavel, P. Are Adolescent Religious Attendance/Spirituality Associated with Family Characteristics? Int. J. Environ. Res. Public Health 2019, 16, 2947. [CrossRef]

21. Bartkowski, J.P.; Xu, X.; Levin, M.L. Religion and child development: Evidence from the early childhood longitudinal study. Soc. Sci. Res. 2008, 37, 18-36. [CrossRef] 
22. Pabian, P. Czech Christianity in a Post-Christian Society. Communio Viat. 2015, 57, 77-89.

23. Hamplová, D. Náboženství v České Společnosti na Prahu 3. Tisíciletí; Karolinum Press: Prague, Czech Republic, 2013.

24. Malinakova, K.; Trnka, R.; Sarnikova, G.; Smekal, V.; Furstova, J.; Tavel, P. Psychometric evaluation of the Daily Spiritual Experience Scale (DSES) in the Czech environment. Ceskoslovenska Psychol. 2018, 62, 100-113.

25. Pew Research Center. Religious belief and national belonging in Central and Eastern Europe. May 2017. Available online: https://www.pewforum.org/2017/05/10/religious-belief-and-national-belonging-in-centraland-eastern-europe/ (accessed on 7 December 2020).

26. STEM. Going to Church at Christmas is a Tradition for Almost Two-Fifths of the Population. 2016. Available online: https://en.stem.cz/going-to-church-at-christmas-is-a-tradition-for-almost-two-fifths-ofthe-population/ (accessed on 7 December 2020).

27. Luzny, D. Czech religiosity at the beginning of the 3rd millennium. Results of the International Social Survey Programme ISSP 2008-Religion. Sociol. Cas.-Czech Sociol. Rev. 2010, 46, 835-838.

28. HBSC International Coordinating Centre; Child \& Adolescent Health Research Unit. HBSC Survey Methods. Available online: http://www.hbsc.org/methods/index.html (accessed on 6 December 2020).

29. Malinakova, K.; Kopcakova, J.; Madarasova Geckova, A.; van Dijk, J.P.; Furstova, J.; Kalman, M.; Tavel, P.; Reijneveld, S.A. "I am spiritual, but not religious": Does one without the other protect against adolescent health-risk behavior? Int. J. Public Health 2019, 64, 115-124. [CrossRef]

30. Currie, C.; Zanotti, C.; Morgan, A.; Currie, D.; De Looze, M.; Roberts, C.; Samdal, O.; Smith, O.R.F.; Barnekow, V. (Eds.) Social Determinants of Health and Well-Being among Young People: Health Behavior in School-Aged Children (HBSC) Study: International Report from the 2009/2010 Survey; Health Policy for Children and Adolescents, No. 6; WHO Regional Office for Europe: Copenhagen, Denmark, 2012.

31. Inchley, J.; Currie, D.; Young, T.; Samdal, O.; Torsheim, T.; Augustson, L.; Mathison, F.; Aleman-Diaz, A.; Molcho, M.; Weber, M.; et al. (Eds.) Growing Up Unequal: Gender and Socioeconomic Differences in Young People's Health and Well-Being: Health Behavior in School-Aged Children (HBSC) Study: International Report from the 2013/2014 Survey; Health Policy for Children and Adolescents, No. 7; WHO Regional Office for Europe: Copenhagen, Denmark, 2016.

32. Badura, P.; Sigmundová, D.; Sigmund, E.; Madarasova Geckova, A.; Van Dijk, J.P.; Reijneveld, S.A. Participation in organized leisure-time activities and risk behaviors in Czech adolescents. Int. J. Public Health 2017, 62, 387-396. [CrossRef]

33. Moore, G.F.; Cox, R.; Evans, R.E.; Hallingberg, B.; Hawkins, J.; Littlecott, H.J.; Long, S.J.; Murphy, S. School, Peer and Family Relationships and Adolescent Substance Use, Subjective Wellbeing and Mental Health Symptoms in Wales: A Cross Sectional Study. Child Indic. Res. 2018, 11, 1951-1965. [CrossRef]

34. Moorem, F.G.; Littlecott, H.J. School- and family-level socioeconomic status and health behaviors: Multilevel analysis of a national survey in wales, United Kingdom. J. Sch. Health 2015, 85, 267-275. [CrossRef]

35. Farhat, T.; Simons-Morton, B.; Luk, J.W. Psychosocial correlates of adolescent marijuana use: Variations by status of marijuana use. Addict. Behav. 2011, 36, 404-407. [CrossRef]

36. Sznitman, S.R.; Kolobov, T.; Ter Bogt, T.; Kuntsche, E.; Walsh, S.D.; Harel-Fisch, Y. Investigating cannabis use normalization by distinguishing between experimental and regular use: A multilevel study in 31 countries. J. Stud. Alcohol Drugs 2015, 76, 181-189. [CrossRef]

37. Van Den Eijnden, R.J.; Lemmens, J.S.; Valkenburg, P.M. The social media disorder scale. Comput. Hum. Behav. 2016, 61, 478-487. [CrossRef]

38. Kub, J.; Solari-Twadell, P.A. Religiosity/Spirituality and Substance Use in Adolescence as Related to Positive Development A Literature Review. J. Addict. Nurs. 2013, 24, 247-262. [CrossRef] [PubMed]

39. Hardy, A.S.; Raffaelli, M. Adolescent religiosity and sexuality: An investigation of reciprocal influences. J. Adolesc. 2003, 26, 731-739. [CrossRef] [PubMed]

40. Ameri, Z.; Mirzakhani, F.; Nabipour, A.R.; Khanjani, N.; Sullman, M.J.M. The Relationship Between Religion and Risky Behaviors Among Iranian University Students. J. Relig. Health 2017, 56, 2010-2022. [CrossRef] [PubMed]

41. Carmack, C.C.; Lewis, R.K. Assessing Whether Religious Behaviors and Positive and Negative Affect are Associated with Alcohol Use and Abuse Among a Sample of College Students Living in the Midwest. J. Relig. Health 2016, 55, 1107-1119. [CrossRef]

42. Desmond, S.A.; Ulmer, J.T.; Bader, C.D. Religion, Self Control, and Substance Use. Deviant Behav. 2013, 34, 384-406. [CrossRef] 
43. Parenteau, S.C. Religious Coping and Substance Use: The Moderating Role of Sex. J. Relig. Health 2017, 56, 380-387. [CrossRef]

44. Queiroz, N.D.R.; Portella, L.F.; Abreu, A.M.M. Association between alcohol and tobacco consumption and religiosity. Acta Paul. De Enferm. 2015, 28, 546-552. [CrossRef]

45. Dohn, M.N.; Méndez, S.A.J.; Pozo, M.N.; Cabrera, E.A.; Dohn, A.L. Alcohol Use and Church Attendance Among Seventh Through Twelfth Grade Students, Dominican Republic, 2011. J. Relig. Health 2014, 53, 675-689. [CrossRef]

46. Hanauer, M.; Walker, M.R.; Machledt, K.; Ragatz, M.; Macy, J.T. Association between perceived risk of harm and self-reported binge drinking, cigarette smoking, and marijuana smoking in young adults. J. Am. Coll. Health 2019, 1-8. [CrossRef]

47. Donath, C.; Gräßel, E.; Baier, D.; Pfeiffer, C.; Bleich, S.; Hillemacher, T. Predictors of binge drinking in adolescents: Ultimate and distal factors-A representative study. BMC Public Health 2012, 12, 263. [CrossRef]

48. Cerkez, I.; Culjak, Z.; Zenic, N.; Sekulic, D.; Kondric, M. Harmful Alcohol Drinking among Adolescents: The Influence of Sport Participation, Religiosity, and Parental Factors. J. Child. Adolesc. Subst. Abus. 2015, 24, 94-101. [CrossRef]

49. Salas-Wright, C.P.; Vaughn, M.G.; Maynard, B.R.; Clark, T.T.; Snyder, S. Public or Private Religiosity: Which Is Protective for Adolescent Substance Use and by What Pathways? Youth Soc. 2017, 49, 228-253. [CrossRef]

50. Kim-Spoon, J.; Longo, G.S.; McCullough, M.E. Adolescents Who Are Less Religious Than Their Parents Are at Risk for Externalizing and Internalizing Symptoms: The Mediating Role of Parent-Adolescent Relationship Quality. J. Fam. Psychol. 2012, 26, 636-641. [CrossRef] [PubMed]

51. Pearce, L.D.; Haynie, D.L. Intergenerational religious dynamics and adolescent delinquency. Soc. Forces 2004, 82, 1553-1572. [CrossRef]

52. Gardner, M.; Steinberg, L. Peer influence on risk taking, risk preference, and risky decision making in adolescence and adulthood: An experimental study. Dev. Psychol. 2005, 41, 625-635. [CrossRef]

53. Patrick, M.E.; Schulenberg, J.E. Alcohol use and heavy episodic drinking prevalence and predictors among national samples of American eighth-and tenth-grade students. J. Stud. Alcohol Drugs 2010, 71, 41-45. [CrossRef]

54. Tome, G.; De Matos, M.G.; Simões, C.; Diniz, J.A.; Camacho, I. How can peer group influence the behavior of adolescents: Explanatory model. Glob. J. Health Sci. 2012, 4, 26-35. [CrossRef]

Publisher's Note: MDPI stays neutral with regard to jurisdictional claims in published maps and institutional affiliations.

(C) 2020 by the authors. Licensee MDPI, Basel, Switzerland. This article is an open access article distributed under the terms and conditions of the Creative Commons Attribution (CC BY) license (http://creativecommons.org/licenses/by/4.0/). 